|| ISSN(online): 2589-8698 || ISSN(print): 2589-868X ||

International Journal of Medical and Biomedical Studies Available Online at www.ijmbs.info

NLM (National Library of Medicine ID: 101738825)

Index Copernicus Value 2019: 79.34

Original Research Article

Volume 5, Issue 8; August: 2021; Page No. 343-344

\title{
PERINATAL OUTCOME OF VAGINAL BREECH DELIVERY VERSUS CAESAREAN BREECH DELIVERY
}

\section{Dr. Rupal Malik ${ }^{1}$, Dr Ritu Gupta ${ }^{2}$}

Resident Doctor, Department of Obstetrics and Gynecology, Jhalawar Medical College, Jhalawar ${ }^{1}$

Senior Professor and Unit Head, Department of Obstetrics and Gynecology, Jhalawar Medical College, Jhalawar ${ }^{2}$

Article Info: Received 19 June 2021; Accepted 27 August 2021

DOI: https://doi.org/10.32553/ijmbs.v5i8.2157

Corresponding author: Dr. Rupal Malik

Conflict of interest: No conflict of interest.

\section{Abstract}

Background: The aim to find out any differences in outcome between vaginal breech delivery and cesarean breech delivery in our setup

Methods: Data were collected from record book of Department of Gynecology and obstetrics. Data of 100 patients were analysed among which 36 underwent vaginal delivery for breech and 64 underwent cesarean breech delivery

Results: Binary logistic regression was used to compare outcome among different groups. In our study only $5.56 \%$ of newborn delivered by vaginal route were admitted to $\mathrm{NCU}$ vs. $12.50 \%$ in cesarean group which was significant (odds ratio $=0.07, \mathrm{P}=0.01$ ) Conclusion:

Keywords: LSCS, Breech, NICU

\section{Introduction}

Breech presentation is a longitudinal lie of the fetus with the caudal pole (buttock or lower extremity) occupying the lower part of the uterus and cephalic pole in the uterine fundus ${ }^{1}$. There are three types of breech presentation. In the frank breech position (48 to $73 \%$ ), both hips are flexed and both knees are extended. In the complete breech position (4.6 to $11.5 \%$ ), both hips and both knees are flexed. In the incomplete breech position (12.4 to 40.5), one or both hips are not completely flexed. ${ }^{2}$

A study done in Lumbini medical college showed that out of 80 selected women with breech presentation, 42 of them had vaginal deliveries and 38 women had undergone caesarean section. The perinatal mortality was $4.8 \%$ and morbidity was $2 \%$ in vaginal breech deliveries. There was no significant difference of APGAR score in the two groups at any time. Similarly, there was no significant difference in perinatal morbidity and mortality in the two groups. Nulliparous women were more likely to deliver by cesarean section. ${ }^{3}$ Another study in Patan Academy of Health Sciences concluded that in well-selected cases, the neonatal outcome following assisted vaginal breech delivery and caesarean section may not be different. ${ }^{4}$

\section{Methods}

Type of study: It is a descriptive cross-sectional study
Study Palace: Department of Obstetrics and Gynecology, Jhalawar Medical College, Jhalawar

Study population: Study Conducted among the pregnant women with breech presentation

Methods of Data Collection: Secondary data were collected from the record of the department. Pregnant with breech presentation who had delivery in the center were enrolled in the study. Data on age of patients, gravida, Parity, living child, abortion, previous neonatal death, period of gestation, mode of delivery (vaginal, cesarean delivery, instrumental) outcome (APGAR score at $1 \mathrm{~min}$ and $5 \mathrm{~min}$, neonatal care unit admission, death, birth injuries) were collected.

Data Analysis: Collected data first entered into Microsoft excel first then analysed using SPSS 25. Mean, frequencies and percentages were calculated for demographic data and categorical variables. Significance of categorical variable was analyzed using Chi square test.

\section{Results}

Data of 100 patients were analyzed among which 36 underwent vaginal delivery for breech and 64 underwent cesarean breech delivery.

Table 1: Frequency table of age group, parity and period of gestation in different mode of delivery

\begin{tabular}{|c|c|c|c|}
\hline Variable & Vaginal delivery $(\mathbf{n}=\mathbf{3 6})$ & LSCS $(\mathbf{n}=\mathbf{6 4})$ & p-value \\
\hline Age $($ mean \pm SD) & $23.12 \pm 2.16$ Yrs & $22.39 \pm 2.09$ Yrs & 0.321 \\
\hline Primi : Multi para & $29: 7$ & $49: 15$ & 0.369 \\
\hline
\end{tabular}


The age \& parity and type of delivery wise difference in both groups were found statistically Insignificant.

Table 2: Binary logistic regression analysis of comparison of outcome among vaginal breech and cesarean breech delivery

\begin{tabular}{|l|l|l|l|l|}
\hline $\begin{array}{l}\text { NICU } \\
\text { admission }\end{array}$ & \multicolumn{1}{|c|}{$\begin{array}{c}\text { Vaginal } \\
\text { delivery(n=36) }\end{array}$} & LSCS (n=64) & $\begin{array}{l}\text { Odd } \\
\text { ratio }\end{array}$ & p-value \\
\cline { 1 - 3 } Yes & $2(5.56 \%)$ & $8(12.50 \%)$ & 0.07 & 0.01 \\
\cline { 1 - 3 } & $34(94.44 \%)$ & $56(87.50 \%)$ & & \\
\hline
\end{tabular}

Binary logistic regression was used to compare outcome among different groups. In our study only $5.56 \%$ of newborn delivered by vaginal route were admitted to NCU vs $12.50 \%$ in cesarean group which was significant (odds ratio $=0.07$, $\mathrm{P}=0.01$ )

\section{Discussion}

With time and advent of safe surgical techniques more and more cesarean breech delivery are being performed worldwide. Cesarean breech delivery is considered safe mode of delivery for breech presentation. ${ }^{5,6,7}$ With more cesarean breech delivery being done, experience for vaginal breech delivery is decreasing so the risk for adverse outcome is increasing. In the centers where vaginal breech delivery is performed more frequently outcome is still good in experienced and skilled hands. ${ }^{8-11}$

Similar to study conducted in Ethopia where prevalence was $3.4 \%{ }^{3} 12.50 \%$ newborn following cesarean breech delivery were admitted in neonatal care unit while $5.56 \%$ of newborn following vaginal breech delivery were admitted in NCU. As a subtotal population in NCU admission is less, superiority of vaginal delivery over cesarean delivery cannot made, further multicenter study with larger sample size is required.

\section{Conclusions}

Though perinatal morbidity was more with cesarean breech delivery but further study with more sample size is needed before reaching conclusion

\section{References}

1. Alan H, Decherney M, Lauren Nathan M, Murphy Goodwin T. Current Diagnosis \& Treatment. 11th ed.; 2007.

2. Steven G, Jennifer Gabe R, Joe Leigh Simpson M. Obstetrics Normal and Problem Pregnancies. 5th ed.; 2007.
3. Mere TD, Handiso TB, Mekiso AB, Jifar MS, Ibrahim SA, Bilato DT. Prevalence and perinatal outcomes of singleton term breech delivery in Wolisso Hospital, Oromia Region, Southern Ethopia: A Cross-Sectional Study. Journal of environmental and Public Health. 2017; Article ID 9413717.

4. Bin YS, Roberts CL, Ford JB, Nicholl MC. Outcomes of breech birth by mode of delivery: a population linkage study. Aust N Z J Obstet Gynaecol. 2016 oct; 56(5):453-9.

5. Hannah ME, Hannah WJ, Hewson SA, Hodnett ED, Saigal S, Wilan AR. Planned caesarean section versus planned vaginal birth for breech presentation at term: a randomised multicentre trial. The Lancet. 2000 October 21;356:1375-83.

6. Charan J, Biswas T. How to calculate Sample Size for different Study Designs in Medical Research. Indian Journal of Psychological Medicine. 2013 April; 35(2):121-6.

7. Berhan Y, Haileamlak A. The risks of planned vaginal breech delivery versus planned caesarean section for term breech birth: a meta-analysis including observational studies. BJOG. 2016 Jan; 123(1):49-57.

8. ACOG committee on obstertic practice. Mode of Term Singleton Breech. In Committee Opinion. 2006.

9. Dohbit JS, Fourmane P, Tochie JN, Momoudou F, Tankeu R, Aletum V, et al. Maternal and neonatal outcomes of vaginal breech delivery for singleton term pregnancies in a carefully selected Cameroonian population: a cohort study. British Medical Journal opens. 2017 Nov 22;7(11):e017198

10. Kostaska A, Menticoglou S, Gagnon R. Vaginal Delivery of Breech Presentation. Journal of Obstetrics and Gynaecology Canada. 2009 June; 31(6):557-66.

11. Fonseca A, Silva R, Rato I, Neves AR, Peixoto C, Ferraz Z, et al. Breech Presentation: Vaginal Versus Cesarean Delivery, which intervention leads to best outcomes? Acta Med Port. 2017 Jun; 30(6):479-8. 